\title{
POTENTIAL EVAPOTRANSPIRATION ESTIMATES FOR NORTHEAST BRAZIL USING GOES-8 DATA
}

\author{
Eduardo J. de Brito Bastos', Jaidete M. de $\operatorname{Souza}^{2}$ \& Tantravahi V. Ramana Rao ${ }^{3}$
}

\begin{abstract}
In this study, an empirical method proposed by Caselles et al. (1992a) is utilized to determine the potential evapotranspiration (ETP) on a regional scale. This method uses the global solar radiation data retrieved by the global radiation model GL1.0, which in turn utilizes data from the visible channel of the GOES-8 satellite. This method is applied to the northeast region of Brazil, using daily and monthly climatological data as the ground truth information to estimate the ETP and the estimated daily ETP data for September, 1997. The methodology involved three steps: 1) to perform a spatial regionalization of the ETP using the method of Ward, which is available in the Statistical Package for the Social Sciences (SPSS); 2) to obtain the correlation between the ETP as estimated by the methods of Jensen \& Haise (1963) - MJH, Caselles (1992a) - MCA, and the Penman's combined method (1948) - MCP; 3) to test the sensibility of the empirical formulations proposed and to assess the estimates using the satellite-based global solar radiation provided by the GL1.0 model. The spatial regionalization shows two distinct regions in the Northeastern Brazil. The MCA yielded better results than the MJH. The ETP estimates using satellite data were satisfactory, showing a maximum error of $20 \%$ when compared with the ground truth data.
\end{abstract}

Key words: Northeast-Brazil, potential evapotranspiration, meteorological satellite

\section{ESTIMATIVA DE EVAPOTRANSPIRAĈ̃O POTENCIAL PARA O NORDESTE DO BRASIL UTILIZANDO DADOS DO GOES-8 \\ RESUMO}

Neste trabalho foi utilizado o método empírico proposto por Caselles et al. (1992a) para determinar a evapotranspiração potencial (ETP) em escala regional. O método utiliza dados de radiação solar global obtidos a partir de um modelo de estimativa da radiação solar global (GL 1.0), que utiliza imagens do canal visível do satélite GOES-8. O método é aplicado no Nordeste do Brasil, utilizando como verdade terrestre dados climatológicos diários e mensais para estimar ETP e dados diários estimados de ETP para setembro de 1997. A metodologia contempla três etapas: 1) regionalização espacial da ETP obtida pelo método de WARD, disponível no software SPSS (Statistical Package for the Social Sciences); 2) correlação entre os valores de ETP estimados pelo método de Jensen \& Haise (1963) MJH, Caselles et al. (1992a) MCA e pelo método combinado de Penman (1948) MCP, respectivamente; e, 3) teste de sensibilidade das formulações empíricas utilizadas e validação dos resultados. A regionalização espacial mostrou duas regiões distintas no Nordeste do Brasil. O MCA apresentou melhores resultados do que o MJH e a ETP estimada, usando dados de satélite, apresentou um erro máximo de $20 \%$, quando comparada com a verdade terrestre.

Palavras-chave: Nordeste do Brasil, evapotranspiração potencial, satélite meteorológico

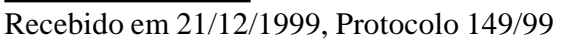

${ }^{1}$ Professor, Doutor em Meteorologia, DCA/CCT/UFPB, CEP 58109 - 970, Campina Grande, PB. Atualmente, Pesquisador Visitante da Divisão de Meteorologia por Satélites/ INPE, CP 515, CEP 12201 - 010, São José dos Campos, SP. E-mail: eduardo@.met.inpe.br

${ }^{2}$ Doutorando em Meteorologia - INPE (Bolsista da CAPES). CEP 12201 - 010, São José dos Campos, SP. E-mail: jaidete@ met.inpe.br

${ }^{3}$ Professor, Doutor em Agrometeorologia, DCA/CCT/UFPB. R. Aprígio Veloso, 882, Bodocongó, CEP 58109 - 090, Campina Grande, PB. E-mail: ramana@dca.ufpb.br 


\section{INTRODUCTION}

The latent heat of evaporation appears in the energy budget equation and it is a key parameter in microclimatological and agrometeorological studies. In addition, the potential evapotranspiration (ETP) is of great use in agronomy because it makes possible to predict harvests with maximum saving of water. Different approaches have been used in determining the ETP with meteorological data (Thornthwaite, 1948; Thornthwaite \& Mather, 1957; Brutsaert, 1982; Jensen et al.,1990; Burman \& Pochop, 1994). Although the accuracy of these methods is good ( $1 \mathrm{~mm}$ of water per day), they are more suitable for local applications $\left(10-100 \mathrm{~m}^{2}\right)$. The high cost of field experiments and the difficulties in measuring the surface fluxes in inaccessible regions resulted in the utilization of alternative techniques in order to complement the available meteorological data.

In this regard, the remote sensing techniques have been intensively used to obtain estimates of the surface and atmospheric parameters, although constrained by the time and space resolutions of the multi-spectral sensors used. Among these techniques, it is important to mention those which allow large area measurements with sensors aboard environmental satellites. The ETP is one of the surface fluxes that is possible to estimate from satellite imagery and the numerous works on its estimation with onboard satellite sensors are all justified due to the importance of this parameter in agriculture, weather modification, etc.

In general, two classes of methods (both using satellite data) have been proposed.: 1) the semi empirical and statistical methods that relates ETP with surface temperature (Vidal and Perrier, 1989); and 2) the analytical or numerical methods based on the solution of the inverse problem for both heat and mass transfers ( Taconet et al., 1986). Important field experiments in the last decade were conducted aiming to combine in situ measurements with remotely sensed data, within the framework of the International Satellite Land-Surface Climatological Project (Becker et al., 1988). In addition, there are many studies on the estimation of the ETP for agricultural regions, using satellite data, such as Taconet et al., (1986); Caselles \& Delegido (1987); Becker \& Li (1990); Rosena \& Fiselier (1990); Caselles et al. (1992a,b).

Taconet et al.(1986) developed a methodology that uses the infrared surface temperature, estimated by using the data obtained from the channels 4 and 5 of NOAA- 7 satellite, as input data to one unidimensional model of boundary layer over vegetated soil surfaces. The model includes a parametrization of the heat transfer between the vegetation and the overlying atmosphere using a small number of mesoscale parameters typical of the vegetation. The model is used to predict the surface fluxes over a dense vegetation and the crop resistance, and to check its results against experimental measurements. In this study three images of a flat region with one type of crop under clear sky conditions were used.

Caselles \& Delegido (1987) adjusted the radiation model proposed by FAO in order to estimate the regional ETP, employing air temperature and albedo data, obtained from NOAA-9 images. The model was then tested for the region of Valencia, Spain. They found new values for the coefficients in the relation established by Doorenbos \& Kassam (1979). Using the same relation, they found a correlation coefficient between the measured ETP and the ETP as estimated by using satellite data, of the order of 0.84 .

Along the same line, Caselles et al. (1992a) utilized the methodology of Caselles \& Delegido (1987) and modified the model to permit the use of AVHRR/NOAA images and checked its validity range for the region of La Mancha, Spain, an area with different regional characteristics for which the model was originally designed. They concluded that the model was successfully modified to accept AVHRR/NOAA data. The correlation between the values of the ETP, estimated from the satellite data and the actually measured data was 0.90 with a standard error of $1.2 \mathrm{~mm} \mathrm{~d}^{-1}$. The surface ETP was estimated from the Penman equation and compared with that obtained from satellite data and concluded that a $10 \%$ variation in the air temperature and in the surface solar radiation implies a less than $10 \%$ variation in the ETP. This method has been used for other regions with the same characteristics of the plot for which the model was first developed. The results are quite satisfactory when the $\mathrm{RH}$ is between 40 and $80 \%$ and the winds are moderate in the range of $200 \mathrm{~km} \mathrm{~d}^{-1}$.

In a different context, Moran et al. (1996) suggested the use of the Penman equation for computing evaporation rates from homogenous surfaces, such as densely vegetated or bare soil regions. The proposed approach was an attempt to use remotely sensed measurements of the surface reflectance and temperature in order to allow the application of the Penman-Monteith theory to partially vegetated fields without a prior knowledge of the percent vegetation coverage and the canopy resistance. The results showed good agreement with those of in situ surface evaporation rate measurements. Later on, the approach was used with a set of four Landsat Thematic Mapper (TM) images for the Southeast Arizona, USA, during 1992. Maps of surface air temperature and wind speed were combined with those of surface temperature and spectral vegetation index to produce regional estimates of evaporation rates for grassland areas. The Penman-Monteith equation becomes more questionable for estimating evaporation rates at regional scales, where the surface is not completely covered by vegetation.

There are relatively few studies on the use of remotely sensed data measured by orbital sensors, for agricultural applications in Brazil. In this context, the present study aims at the estimation of the ETP using an empirical formulation and surface global solar radiation data inferred from the visible channel of the meteorological satellite GOES-8.

\section{MATERIAL AND METHODS}

\section{Surface and satellite data}

Monthly and daily climatological air temperature and solar radiation data, air temperature, relative humidity, wind speed and direction, evaporation and sunshine duration for September 1997 used in this study were provided by the Laboratory for Processing Meteorological Information (LAPIM), Department of Atmospheric Sciences, Universidade Federal da Paraíba and the daily data for the month of September were obtained from the INMET (Instituto Nacional de Meteorologia). 
The monthly climatological air temperature data cover the period of 1912 through 1980, while the solar radiation data cover only 1968 through 1978 . Regarding the daily climatological data, air temperatures refer to the 1961-1979 period and the solar radiation, collected by the solarimetric network of the Northeast Brazil, for the 1970-1978 period only.

The GOES-8 visible channel images for the month of 1997, utilized in this study, were provided by the CPTEC (Centro de Previsão de Tempo e Estudos Climáticos do Instituto Nacional de Pesquisas Espaciais). The $434 \times 525$ pixel images cover the Northeast Brazil, between $1^{\circ} \mathrm{S}-18^{\circ} \mathrm{S}$ and $31^{\circ} \mathrm{W}-47^{\circ} \mathrm{W}$.

\section{Methods}

The ETP was estimated using the daily climatological data of air temperature and the empirical formulae of Thornthwaite (1948). These estimates were used to determine the spatial regionalization for the entire Northeast Brazil. The grouping was obtained through the hierarchical classification method of Ward, using the Euclidean distance as the similarity measure (Ward, 1963).

Using the daily climatological data available for September 1997, the ETP was calculated by employing the Penman's Combined Method (Penman, 1948) - MCP, the method proposed by Caselles et al. (1992b) - MCA and the method of Jensen \& Haise (1963) - MJH. The correlation was performed to assess the MJH and MCA, taking the ground truth estimates made with the standard MCP. A sensitivity analysis of the equations of Jensen \& Haise (1963) and Caselles et al. (1992b) in terms of global solar radiation and the air temperature was carried out. This analysis determined how much the ETP depends on the global solar radiation and the air temperature.

The surface global solar radiation was obtained with the radiation model GL1.0, using the VIS channel data from the meteorological satellite GOES-8.

The method of Caselles et al (1992b) is described below, together with considerations on the method used to obtain the regionalization and the method to estimate the global solar radiation (radiation model GL1.0).

According Caselles et al. (1992b), the ETP is calculated by:

$$
\mathrm{ETP}=(\mathrm{A} \mathrm{Ta}+\mathrm{B}) \operatorname{Rg}+\mathrm{C}
$$

where $\mathrm{A}, \mathrm{B}$ and $\mathrm{C}$ are empirical constants determined for each region since they depend on the altitude, relative humidity and wind speed; Ta is the air temperature and $\mathrm{Rg}$ is the global solar radiation, the last two parameters being calculated from satellite images. The numerical values of the constants are $\mathrm{A}=5.99 \times 10^{-4}, \mathrm{~B}=5.06 \times 10^{-6}$ and $\mathrm{C}=0.37$.

The estimation of solar radiation with satellite techniques is achieved by means of a physical model which establishes the relation between the observed fluxes at the top of the atmosphere and at the ground surface through the radiation transfer equation (Gautier et al., 1980; Stuhlmann et al., 1990; Whitlock et al., 1995; Ceballos \& Moura, 1997). The GL1.0 is a physical model developed at the Universidade Federal da Paraíba (UFPB) for the VIS channel images of the Meteosat 4 satellite (Ceballos \& Moura, 1997), and later adapted to the VIS channel of the GOES by researchers from the Department of Meteorological Sciences of the INPE and the UFPB
(Bastos et al., 1996). The preliminary version was implemented at CPTEC/INPE with some modifications and it provides daily, weekly and monthly distributions of global solar radiation.

The model estimates the solar radiation by splitting the flux into two parts referring to the visible $(0.4-0.7 \mu \mathrm{m})$ and to the infra-red $(0.7-4.0 \mu \mathrm{m})$ bands. The radiative budget equation for the earth-atmosphere system is:

$$
\mathrm{Eo}(\mathrm{vis})=\mathrm{ER}(\mathrm{vis})+\mathrm{EA}(\mathrm{vis})+(1-\mathrm{Rs}) * \mathrm{GL}(\mathrm{vis})
$$

where Eo is the solar irradiance impinging on the top of the atmosphere; ER is the reflected irradiance back into the space; EA is the absorbed irradiance by the atmosphere; Rs is the surface reflectance and GL is the global irradiance reaching the surface.

The solar infrared irradiance may be estimated by the following equation:

$$
\mathrm{GL}(\mathrm{ir})=\frac{(1-\mathrm{C}) * \mathrm{Tg} * \mathrm{Eo}(\mathrm{ir})}{[1-\mathrm{Rs}(\mathrm{ir}) * \mathrm{C} * \mathrm{Rn}(\mathrm{ir})]}
$$

where $\mathrm{Tg}$ is the transmittance associated with gases; $\mathrm{C}$ is the cloudiness; Rs (ir) is the soil infra-red reflectance and $\mathrm{Rn}$ (ir) is the infra-red reflectance from the cloud bases. The denominator of Eq. (3) contains a correction factor due to multiple reflections between the surface and the cloud bases.

The cloudiness is estimated with the aid of:

$$
\mathrm{C}=\frac{(\mathrm{R}-\mathrm{R} \min )}{(\mathrm{R} \max -\mathrm{R} \min )}
$$

where $\mathrm{R}$ is the observed reflectance at one target (visible channel) and, Rmax and Rmin are the observed extreme values, estimated from a series of images taken around the day considered in the study.

The surface irradiance is estimated by summing GL(vis) + GL(ir) $=$ GL. The model uses $3 \times 3$ pixel averages over the targets . This is done to ensure coherence between the size of the target (satellite) and the interval used in the time average (station).

\section{RESULTS AND DISCUSSION}

The Ward's method was applied to the ETP matrix for the Northeast Brazil (NEB). The ETP was estimated from the method of Thornthwaite (1948), which uses only the air temperature. The final result obtained with the Ward's method is given under a dendrogram, which shows the subdivisions of the groups with the same characteristics, thus forming one single group. A number of groups were chosen by analyzing the dendrogram to define the sub-regions in the Northeast Brazil, as shown in Figure 1.

The shaded area designated as sub-region 1 of Figure 2 shows the regionalization of the ETP for the interior and the northern coastal region of the NEB and the sub-region 2 shows the regionalization of the ETP for the eastern coastline of the NEB. These two homogenous regions were obtained by analyzing the dendrogram shown in Figure 1. 


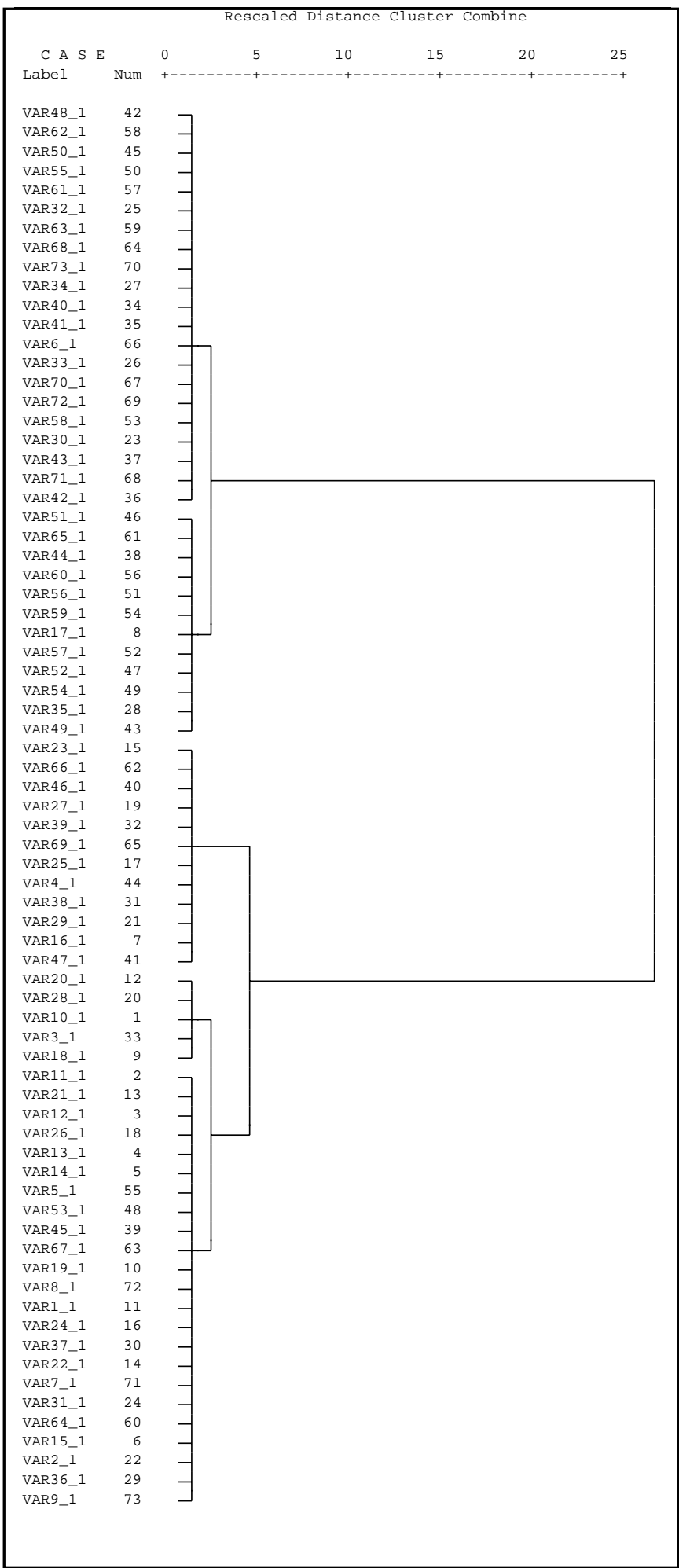

Figure 1. Rescaled distance cluster combine of ETP regionalization using the method of Ward

The number of stations for each group, after the regionalization, was of 33 for the eastern coast and 40 for the northern coast and the interior of NEB, totaling 73 stations. The northern coastal area and the hinterlands have higher air temperature than the eastern coast, thus the evapotranspiration rate is distinct for these regions, according to the regionalization. The eastern coastal area is more affected by various weather systems such as the sea breeze, eastern waves, cold fronts

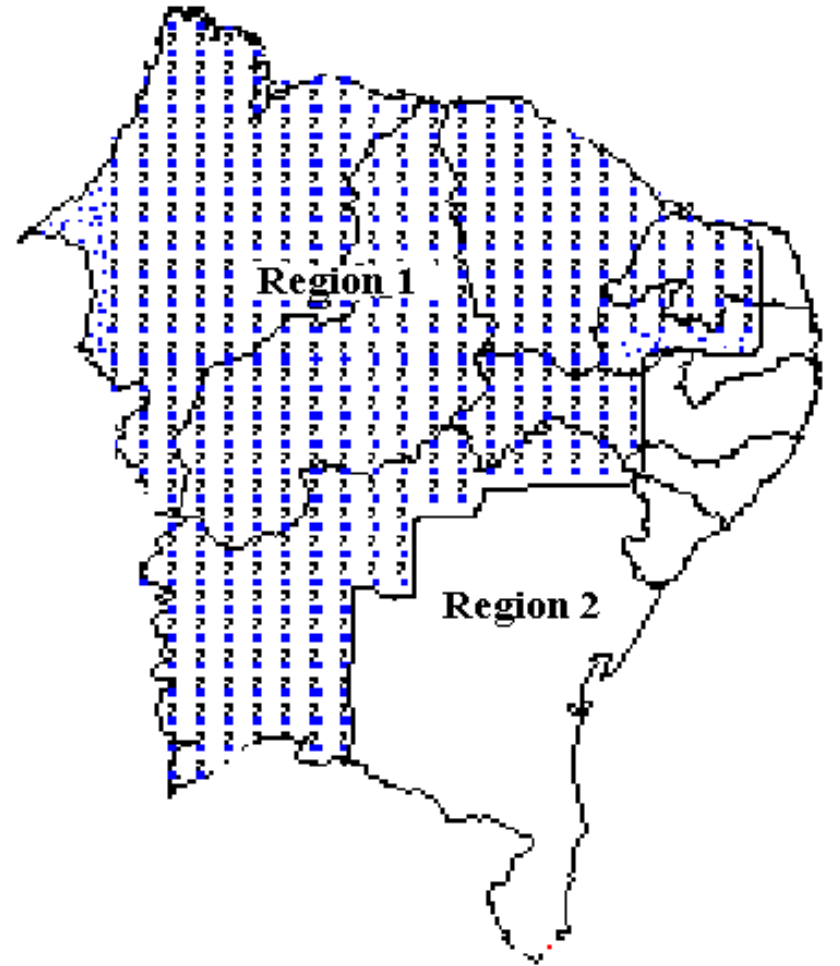

Figure 2. Regionalization of the ETP for the Northeast-Brazil region

from the southern part of the country, while the atmospheric circulation over the hinterlands is driven primarily by orographic effects.

Some regionalization studies were made for this region using other variables such as the surface global radiation (Souza \& Ceballos, 1996) and the precipitation (Lopes et al., 1996), among others. In general, the results are in agreement with the regionalization given in Figure 2, although it must be said that this regionalization is limited due to the method of estimating the ETP. This suggests that other variables, including those referring to the soil and vegetation, are necessary to obtain a better regionalization.

The method of estimating the ETP as a function of the surface solar radiation and the air temperature is of great importance. For this purpose, the MCA and MJH equations were obtained by using the air temperature and the surface global radiation. It was observed that a variation of $18 \mathrm{~W} \mathrm{~m}^{-2}$ in the global solar radiation implied a change of about $9 \%$ in the ETP estimate, and a variation of $2{ }^{\circ} \mathrm{C}$ in the air temperature produced a change of $6 \%$ in the ETP estimate obtained from the MCA method.

Figures $3 \mathrm{~A}$ and $\mathrm{B}$ show the changes in the ETP estimates as a function of global solar radiation and the air temperature. For higher values of the global solar radiation, the ETP changes more rapidly as a function of temperature than in the case of the lower values of solar radiation. This was observed for both MCA and MJH estimates. The estimates of the ETP using the MCA method were found to be larger, of the order of $1 \mathrm{~mm}$, than those obtained with the MJH method.

An estimate of the daily ETP for September, 1997 was obtained by using the MCP, the MCA and the MJH methods. The MCP method was one of the earliest methods to consider 


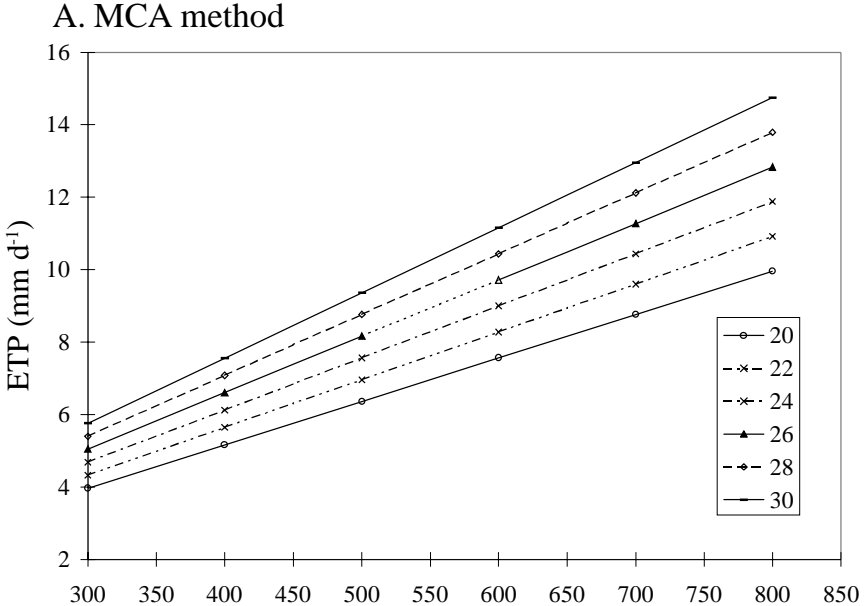

B. MJH method

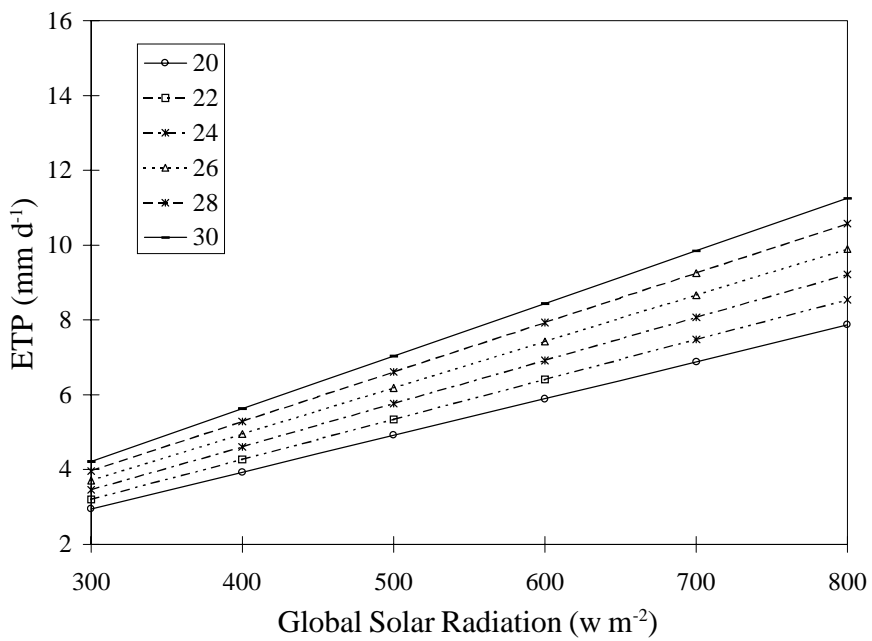

Figure 3. Variation of the ETP $\left(\mathrm{mm} \mathrm{d}^{-1}\right)$ with global solar radiation for different air temperatures $\left({ }^{\circ} \mathrm{C}\right)$ using the (A) MCA and (B) MJH method

energy supply and turbulent transport. Among the radiation methods, the $\mathrm{MJH}$ is one that includes not only the solar radiation but also the air temperature, and whose original formulation was based on the data collected over the arid regions of the western part of the USA.

The main objective of a regression equation is to provide means to estimate one variable, given the value of another, and to validate methods. From this viewpoint, the correlation coefficient measures the extent of association between the variables, or in the case of this study, the association among various methods of estimating the ETP. One way to represent the relation among them is to establish a linear regression equation and use it to validate the particular method employed.

The correlation analysis were conducted on: 1) all the stations; 2) all the stations along the coastal areas and 3) all the stations in the interior of NEB. The estimates of ETP using the MJH and MCA methods were compared with that of the MCP method. The MCA method showed a good correlation with the MCP method, hence justifying its use in estimating ETP in the region, besides being more realistic than the $\mathrm{MJH}$ method. However, the MCA and MJH methods both overestimated the ETP, when compared with the MCP estimate.

Figures $4 \mathrm{~A}, 4 \mathrm{~B}$ and $4 \mathrm{C}$ show the correlations and the linear equations obtained for all the correlations executed. The
A. All the stations
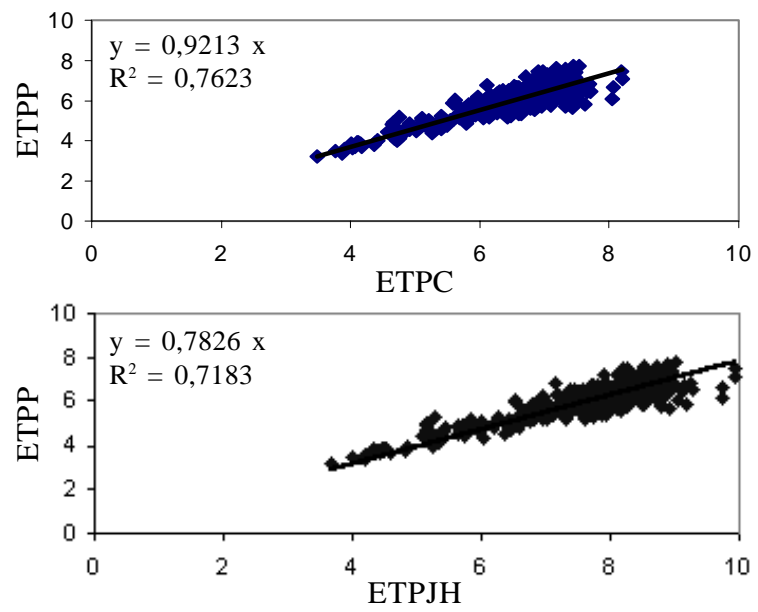

B. Stations along the costal areas
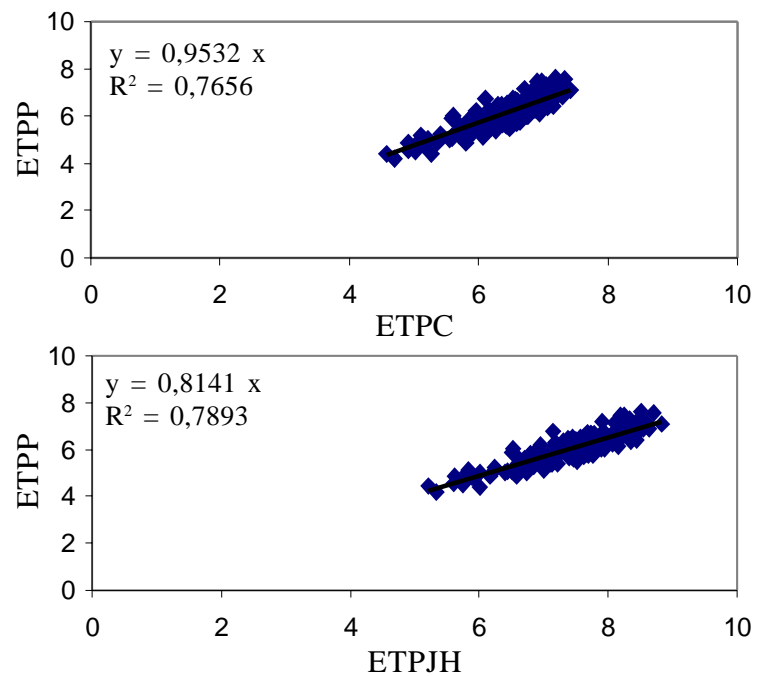

C. Stations in the interior of NEB
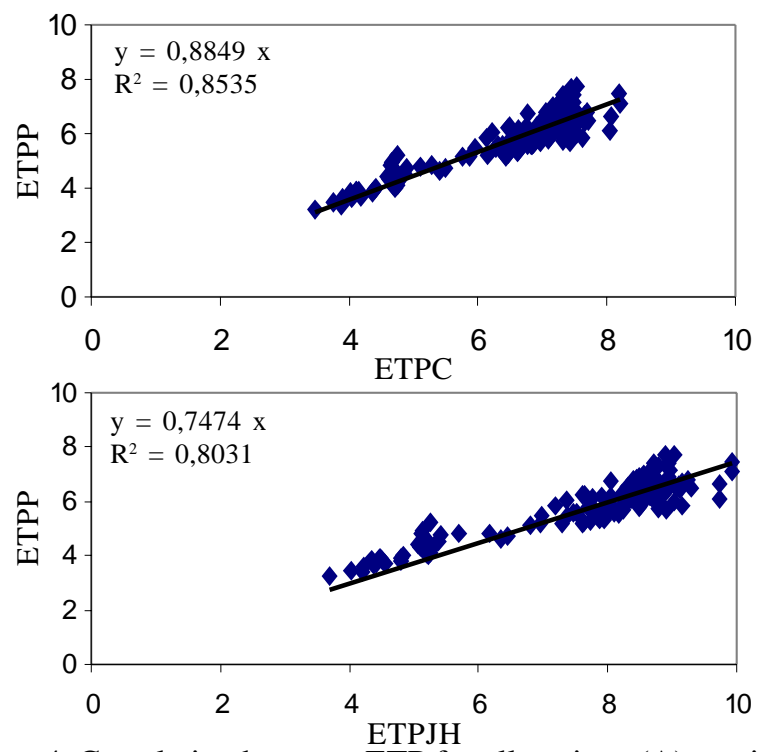

Figure 4. Correlation between ETP for all stations (A), stations along the costal areas (B) and stations in the interior of Northeast Brazil (NEB) (C) estimated by using the method of Penmam (ETPP) and by methods of Caselles et al. (ETPC) and Jensen \& Haíse (MJH)

correlation coefficients for the stations along the coastal area are about the same for the cases MCA x MCP and MJH x MCP, 
but for the stations in the interior of NEB, the correlation coefficients were higher in the MCA x MCP comparison than in the MJH x MCP case. This indicates that the coefficients of the regression equations are dependent on the characteristics of the region. The correlation coefficients for all the stations, although significant, were smaller than those of the stations in the interior, clearly reflecting the different natures of the weather systems that affect the inland and coastal areas.

Although the MCA method was developed for the region of La Mancha, Spain, its results may be considered satisfactory and justify the use of this method to estimate ETP in the NEB. Nevertheless, the discrepancies found between the MCA x $\mathrm{MCP}$ and MJH x MCP correlation studies are suggestive that adjustments are needed in order to use the method in agronomic, agrometeorological and meteorological applications.

Figure 5 shows curves of daily ETP for September, 1997 calculated using the MCP method (ETPP), the MCA method using surface meteorological data (ETPCSUP) and the same method again using global solar radiation data retrieved from the satellite measurements (ETPCSAT). There is a reasonable consistency, although the MCA calculated values overestimate the MCP results (as mentioned in the literature, the empirical methods always do that). In general, the differences are smaller than $20 \%$ or $1.5 \mathrm{~mm} \mathrm{~d}^{-1}$. It was also observed that there are days with a pronounced discrepancy, because when the ETP increases the ETPCSAT decreases, and vice-versa. This is probably due to the days with few images introducing errors in the determination of the surface global solar radiation.

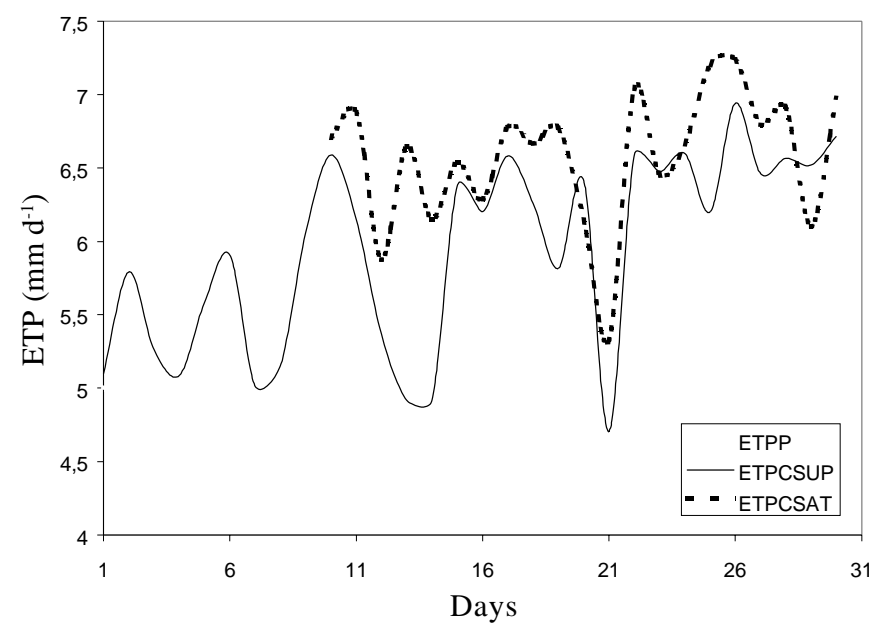

Figure 5. Comparison between the ETP estimates by MCP (ETPP) and MCA (ETPCSUP and ETPCSAT)

\section{CONCLUSIONS}

The main results achieved by this study may be summarized as follows:

1. There are two distinct regions in the Northeastern Brazil regarding the distribution of ETP.

2. The MCA method yields better results than the MJH method.

3. The ETP estimates using satellite data are quite acceptable, within a maximum error of $20 \%$ when checked against the ground truth.

\section{REFERENCES}

BASTOS, E.J.B; FUNATSU, B.M.; BONFIM, A.; MORAES, E.C.; CEBALLOS, J.C. Estimativa da radiação solar global para América do Sul via satélite. In: CONGRESSO BRASILEIRO DE METEOROLOGIA, IX, 1996, Campos do Jordão. Anais... 1996. v.1, p.596-600.

BECKER, F.; BOLLE, H.J.; ROWNTREE, P.R. The international satellite land seafore climatology project. Berlin: Free University of Berlin Press, 1988, 100p.

BECKER, F.; LI, Z. Towards a local split window method over land surfaces. International Journal of Remote Sensing, Basingstoke. v.11, n.3, p.369-393, 1990.

BRUTSAERT, W. Evaporation into the atmosphere: Theory, history and applications. The Dordrecht Netherlands: Reidel, 1982.345p.

BURMAN, R.; POCHOP, L.O. Evaporation, evapotranspiration and climatic data. Amsterdam: Elsevier. 278p, 1994.

CASELLES, V.; DELEGIDO, J.A. Simple model to estimate the daily value of the regional maximum evapotranspiration from satellite temperature and albedo images. International Journal of Remote Sensing, Basingstoke. v.8, p.1151-1162, 1987.

CASELLES, V.; DELEGIDO, J.; HURTADO, E.; SOBRINO, J.A. Evaluation of the maximum evapotranspiration over the La Mancha region, Spain, by use of NOAA AVHRR data. International Journal of Remote Sensing, Basingstoke. v.13, p.939-946, 1992a.

CASELLES, V.; HURTADO, E.; SOBRINO, J.A. Maximum evapotranspiration through NOAA satellite images: application to La Mancha region, Spain. Atmospheric Research, New York. v.b28, p.365-374, $1992 b$.

CEBALLOS, J.C.; MOURA, G. Solar radiation assessment using Meteosat-4 VIS imagery. Solar Energy, Elmsford. v.60, p.209-219, 1997.

DOORENBOS, J.; KASSAM, A.H. Yield response to water. Rome: FAO, 1979. 139p. FAO Irrigation and Drainage Paper, 33

GAUTIER, C.; DIAK, G.; MASSE, S. A simple physical model to estimate incident solar radiation at the surface from GOES satellite data. Journal of Applied Meteorology, Boston. v.19, n.8, p.1005-1012, 1980.

JENSEN, M.E.; BURMAN, R.D.; ELLEN. R.G. (Eds.) Evapotranspiration and irrigation water requirements. New York: ASCE, 1990, 332p.

JENSEN, M.E.; HAISE, H.R. Estimating evapotranspiration from solar radiation. Journal of Irrigation and Drainage of the ASCE, New York. v.89, p.15-41, 1963.

LOPES, P.M.O., SILVA, B.B., RODRIGUES, M.F.G. Identificação de grupos pluviometricamente homogêneos no Estado do Rio Grande do Norte. In: CONGRESSO BRASILEIRO DE METEOROLOGIA, IX, 1996, Campos do Jordão. Anais... 1996. v.1, p.272-275.

MORAN, M.S.; RAHMAN, A.F.; WASHBURNE, J.C.; GOODRICH, D.C.; WELTZ, M.A.; KUSTAS, W.P. Combining the Penman-Montheith equation with measurements of surface temperature and reflectance to estimate evaporation rates of semi-arid grassland. Agricultural and Forest Meteorology, New York, v.80, p.87-109, 1996. 
PENMAN, H.L. Natural evaporation from open water, bare soil and grass. Proceedings of the Royal Society. A- Series, London. v.193, p.120-145, 1948.

ROSENA, A.; FISELIER, J.L. Meteosat-based evapotranspiration and thermal inertia mapping for monitoring transgression in the Lake Chad region and Niger Delta. International Journal of Remote Sensing, Basingstoke. v.11, p.741-752, 1990.

SOUZA, J.M.; CEBALLOS, J.C. Campos de correlação e a distribuição de estações na rede solarimétrica do Nordeste. In: CONGRESSO BRASILEIRO DE METEOROLOGIA, IX, 1996, Campos do Jordão. Anais... 1996. v.1, p.673-676.

STUHLMANN, R.; RIELAND, M.; RASCHKE, E. An improvement of the IGMK model to derive total and diffuse solar radiation at the surface from satellite data. Journal of Applied Meteorology, Boston. v. 29, n.7, p.586-603, 1990.

TACONET, O.; BERNARD, R.; VIDAL-MADJAR, D. Evapotranspiration over an agricultural region using a surface flux/temperature model based on NOAA-AVHRR data. Journal of Climate and Applied Meteorology, Boston. v.25, p.284-307, 1986.
THORNTHWAITE, C.W. An approach toward a rational classification of climate. Geographical Reviews, New York. v.38, p.55-94, 1948.

THORNTHWAITE, C.W.; MATHER, J.R. Instructions and tables for computing potential evapotranpiration and the water balance. New Jersey: Drexel Institute of Technology. 1957, 311p.

VIDAL, A.; PERRIER, A. Analysis of a simplified relation for estimating daily evaporation from satellite thermal IR data. International Journal of Remote Sensing, Basingstoke, v.10, p.1327-1337, 1989.

WARD, J.H. Heirarchical grouping to optimize an objective function. Journal of American Statistics Association, Washington, v.58, p.236-244, 1963.

WHITLOCK, C.H.; CHARLOCK, T.P.; STAYLOR, W.F.; PINKER, R.T.; LASZLO, I.; OHMURA, A.; GILGEN, H.; KONGELMAN, T.; DI PASQUALE, R.C.; MOATS, C.D.; LE CROY, S.R.; RITCHEY, N.A. First global WCRP short wave surface radiation budget data set. Bulletin of American Meteorological Society, Boston, v.76, p.905-922, 1995. 